\title{
Penerapan Algoritma Simple Additive Weighting untuk Membantu Dalam Menentukan Calon Penerima Bantuan Pangan Non Tunai
}

\author{
Andri Andreas ${ }^{1)}$, Antonius Wiryadinata ${ }^{2}$, Halim Agung ${ }^{3)}$ \\ Teknik Informatika, Fakultas Teknologi dan Desain, Univeristas Bunda Mulia \\ Jalan Lodan Raya No. 2, Pademangan, Jakarta Utara, 14430 \\ 1)Email: thioandri7@gmail.com \\ 2)Email: antoniuswiryadinata@ymail.com \\ 3)Email:hagung@bundamulia.ac.id
}

\begin{abstract}
Bantuan Pangan Non Tunai (BPNT) is a program organized by the government in overcoming poverty and food needs. The BPNT program aims to reduce the burden of expenditure and provide more balanced nutrition to Beneficiary Families (KPM). However, in the implementation of the BPNT program there were still technical problems, including the determination of potential BPNT recipients who were wrongly targeted. To facilitate Government in determining prospective BPNT recipients, the authors make a decision support system using the Simple Additive Weighting method where this system generates ranking to choose citizens who are entitled to receive BPNT through calculating the criteria of each alternative. It is expected that this application can provide recommendations for prospective $B P N T$ recipients who are more targeted.
\end{abstract}

Keywords: BPNT, criteria, decision support system, SAW, weight

\begin{abstract}
Abstrak: Bantuan Pangan Non Tunai (BPNT) merupakan program yang diselenggarakan pemerintah dalam menanggulangi kemiskinan dan kebutuhan pangan. Program BPNT ini bertujuan untuk mengurangi beban pengeluaran serta memberikan nutrisi yang lebih seimbang kepada Keluarga Penerima Manfaat (KPM). Namun dalam pelaksanaannya program BPNT ini masih terdapat permasalahan teknis, diantaranya penentuan calon penerima BPNT yang salah sasaran. Untuk mempermudah pejabat terkait dalam menentukan calon penerima BPNT, maka penulis membuat sebuah sistem pendukung keputusan dengan menggunakan metode Simple Additive Weighting dimana sistem ini menghasilkan perangkingan sebagai rekomendasi warga yang berhak menerima BPNT melalui perhitungan bobot kriteria dari setiap alternatif. Diharapkan aplikasi ini dapat memberikan rekomendasi calon penerima BPNT yang lebih tepat sasaran.
\end{abstract}

Kata kunci: bobot, BPNT, kriteria, SAW, sistem pendukung keputusan

\section{PENDAHULUAN}

Kemiskinan menjadi salah satu permasalahan yang harus di perhatikan oleh pemerintah baik pusat maupun daerah. Berdasarkan hasil Survey Sosial Ekonomi Nasional (SUSENAS) Badan Pusat Statistik (BPS) pada tahun 2017, mencatat garis kemiskinan DKI sebesar Rp 536.546 per kapita per bulan [1]. KEMSOS telah menentukan kriteriakriteria yang dapat dijadikan pedoman oleh para pemangku kepentingan dalam menentukan calon penerima BPNT. Namun dalam tingkat operasional masih terdapat kesalahan teknis dimana penerima BPNT tidak sesuai dengan kriteria yang telah ditentukan oleh KEMSOS. Selama ini perhitungan dilakukan secara manual tanpa menggunakan suatu metode dan hanya menggunakan usulan-usulan. Agar proses pengelolaan dan perhitungan lebih efektif dan efisien maka dibuat sebuah sistem pendukung keputusan dengan menerapkan sebuah metode, yaitu metode SAW (Simple Additive Weighting). Konsep dasar SAW adalah mencari penjumlahan terbobot dari rating kinerja pada setiap kinerja alternatif pada semua atribut, tetapi perlu diingat bahwa SPK hanya untuk memberikan alternatif pilihan bukan untuk menentukan keputusan akhir. Dengan metode ini akan didapatkan perhitungan yang sesuai dengan kriteria sehingga lebih tepat sasaran.

Pada penelitian terdahulu yang menggunakan metode SAW yang berjudul Sistem Pendukung 
Keputusan Seleksi Penerimaan Beras untuk Keluarga Miskin dengan Metode Simple Additive Weighting [2], peneliti menggunakan metode SAW untuk menyeleksi siapa saja yang berhak menerima raskin. Yang sekarang program raskin telah digantikan dengan program BPNT.

Lalu pada penelitian yang berjudul Rancang Bangun Sistem Pendukung Keputusan Penerima Beasiswa dengan Metode SAW [3]. Peneliti menentukan nilai bobot sesuai dengan nilai kriteria.

\section{METODE PENELITIAN}

BPNT adalah bantuan pangan dari pemerintah yang diberikan kepada KPM setiap bulannya melalui mekanisme akun elektronik yang digunakan hanya untuk membeli pangan di e-Warong KUBE PKH / pedagang bahan pangan yang bekerjasama dengan Bank HIMBARA [4]. BPNT bertujuan untuk mengurangi beban pengeluaran serta memberikan nutrisi yang lebih seimbang kepada Keluarga Penerima Manfaat (KPM) secara tepat sasaran dan tepat waktu.

Simple Additive Weighting Method (SAW) sering juga dikenal dengan metode penjumlahan terbobot [5]. Konsep dasar metode SAW, adalah mencari penjumlahan terbobot dari rating kinerja pada setiap alternatif dari semua atribut, metode SAW membutuhkan proses normalisasi matrik keputusan (x) ke suatu skala yang dapat diperbandingkan dengan dengan semua rating alternatif yang ada Adapun langkah-langkah penyelesaian SAW [6]:

1. Menetukan alternatif $A_{i}$

2. Menentukan kriteria yang akan dijadikan acuan dalam pengambilan keputusan, yaitu $\mathrm{C}_{\mathrm{j}}$.

3. Memberikan nilai rating kecocokan setiap alternatif pada setiap kriteria.

4. Menentukan bobot preferensi atau tingkat kepentingan (W) setiap kriteria.

$$
W=\left[\begin{array}{lllll}
W_{1} & W_{2} & W_{3} & \ldots & W_{j}
\end{array}\right]
$$

5. Membuat tabel rating kecocokan dari setiap alternatif pada setiap kriteria.

6. Membuat matrik keputusan $X$ yang dibentuk dari tabel rating kecocokan dari setiap alternatif pada setiap kriteria. Nilai $\mathrm{x}$ setiap alternatif $\left(\mathrm{A}_{\mathrm{i}}\right)$ pada setiap criteria $\left(\mathrm{C}_{\mathrm{j}}\right)$ yang sudah ditentukan, dimana, $\mathrm{i}=1,2, \ldots \mathrm{m}$ dan $\mathrm{j}=1,2, \ldots \mathrm{n}$.

$$
X=\left[\begin{array}{cccc}
x_{11} & x_{12} & \cdots & x_{1 j}- \\
& \vdots & & \\
x_{11} & x_{12} & \cdots & x_{1 j}
\end{array}\right.
$$

7. Melakukan normalisasi matrik keputusan dengan cara menghitung nilai rating kinerja ternomalisasi $\left(r_{i j}\right)$ dari alternatif $A_{i}$ pada kriteria $C_{j}$.

$$
r_{i j}=\left\{\begin{array}{l}
\frac{x_{i j}}{\operatorname{Max}_{i}\left(x_{i j}\right)} \text { jikaj adalah kriteria Benefin } \\
\frac{\operatorname{Min}_{i}\left(x_{i j}\right)}{x_{i j}} \text { jikaj adalah kriteria Cost }
\end{array}\right.
$$

8. Hasil dari nilai rating kinerja ternomalisasi $\left(\mathrm{r}_{\mathrm{ij}}\right)$ membentuk matrik ternormalisasi (R)

$$
R=\left[\begin{array}{cccc}
r_{11} & r_{12} & \cdots & r_{1 j} \\
r_{i 1} & r_{12} & \cdots & r_{i j}
\end{array}\right]
$$

9. Hasil akhir nilai preferensi $\left(\mathrm{V}_{\mathrm{i}}\right)$ diperoleh dari penjumlahan dari perkalian elemen baris matrik ternormalisasi (R) dengan bobot preferensi (W) yang bersesuaian eleman kolom matrik (W).

$$
V_{i}=\sum_{j=1}^{n} w_{j} r_{i j}
$$

Hasil perhitungan nilai $V_{i}$ yang lebih besar mengindikasikan bahwa alternatif $\mathrm{A}_{i}$ merupakan alternatif terbaik.

Sistem Pendukung Keputusan adalah sistem yang dibuat untuk membantu tahapan dalam mengambil keputusan seperti mengenali masalah, memilih data yang relevan, dan pendekatan yang dilakukan dalam mengevaluasi alternatif pilihan [8].

Untuk perancangan analisis ini digunakan model waterfall untuk menganalisis aplikasi yang akan dirancang. Adapun tahapan-tahapannya adalah:

1. Requirement Analysis. Pada tahap ini dilakukan analisa terhadap kebutuhan sistem dengan melakukan pengumpulan data seperti wawancara dan analisis dokumen.

2. System Design. Tahapan design ini dimodelkan melalui flowchart untuk keseluruhan sistem. Untuk basis datanya menggunakan Entity Relationship Diagram.

3. Implementation. Melakukan penulisan kode program yang merupakan implementasi dari desain yang telah dibuat dengan bahasa PHP, Javascript, dan basis data MYSQL.

4. Testing. Pengujian sistem dengan tujuan mencari kesalahan dan kekurangan yang nantinya akan diperbaiki. Dilakukan dengan metode black box.

5. Deployment. Software yang telah diuji dan siap diimplementasikan kedalam sistem pengguna / sudah siap diterapkan.

6. Maintenance. Tahap terakhir, sistem yang telah diimplemantasikan masih bisa mengalami perubahan karena kerusakan ataupun tambahan fungsional yang terjadi guna meraih tujuan penggunaannya. 
Bagan alir atau flowchart digunakan terutama untuk alat bantu komunikasi dan untuk dokumentasi. Flowchart sistem ditunjukkan pada Gambar 1.

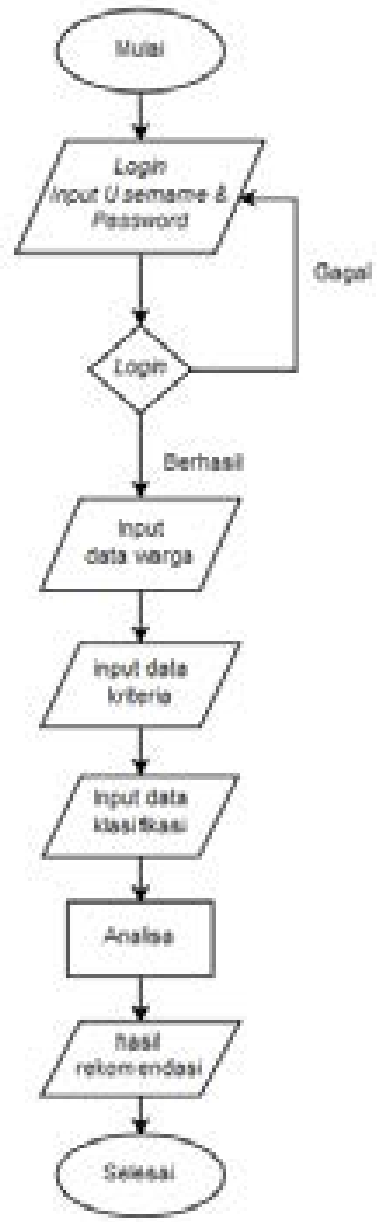

Gambar 1 Flowchart sistem
Entity Relationship Diagram (ERD) menggambarkan jenis hubungan diantara berbagai entitas yang terlibat dalam sistem pendukung keputusan calon penerima BPNT. ERD digambarkan menggunakan physical data model. Model inilah yang nantinya akan diterapkan menjadi tabel-tabel di database, seperti pada Gambar 2.

Diagram Konteks menggambarkan secara garis besar aliran input dan output. Diagram ini mencatat data yang masuk ke sistem beserta sumbernya serta informasi yang dihasilkan oleh sistem. Pada Gambar 3 , terdapat sebuah entitas yang berhubungan langsung dengan sistem pendukung yaitu entitas admin. Admin dapat melakukan pengelolaan data warga, kriteria, himpunan dan klasifikasi. Sistem dapat melakukan analisa dan menampilkan hasil perankingan kepada admin atau petugas terkait.

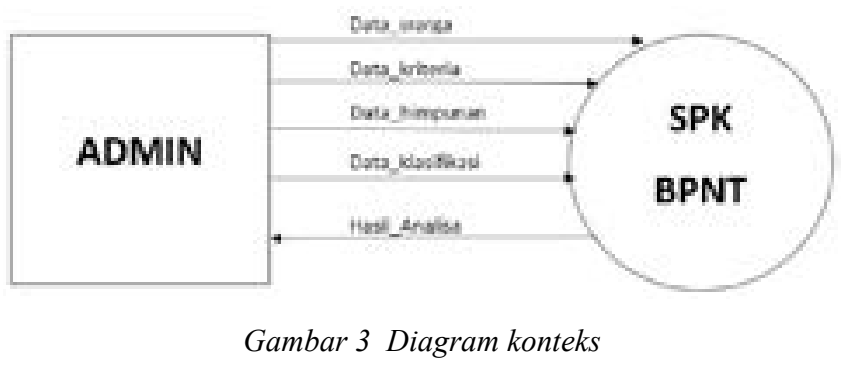

Pada Gambar 4 menampilkan DFD level 0 yang menggambarkan alur proses kerja sistem secara rinci termasuk sumber pengambilan dan penyimpanan data.

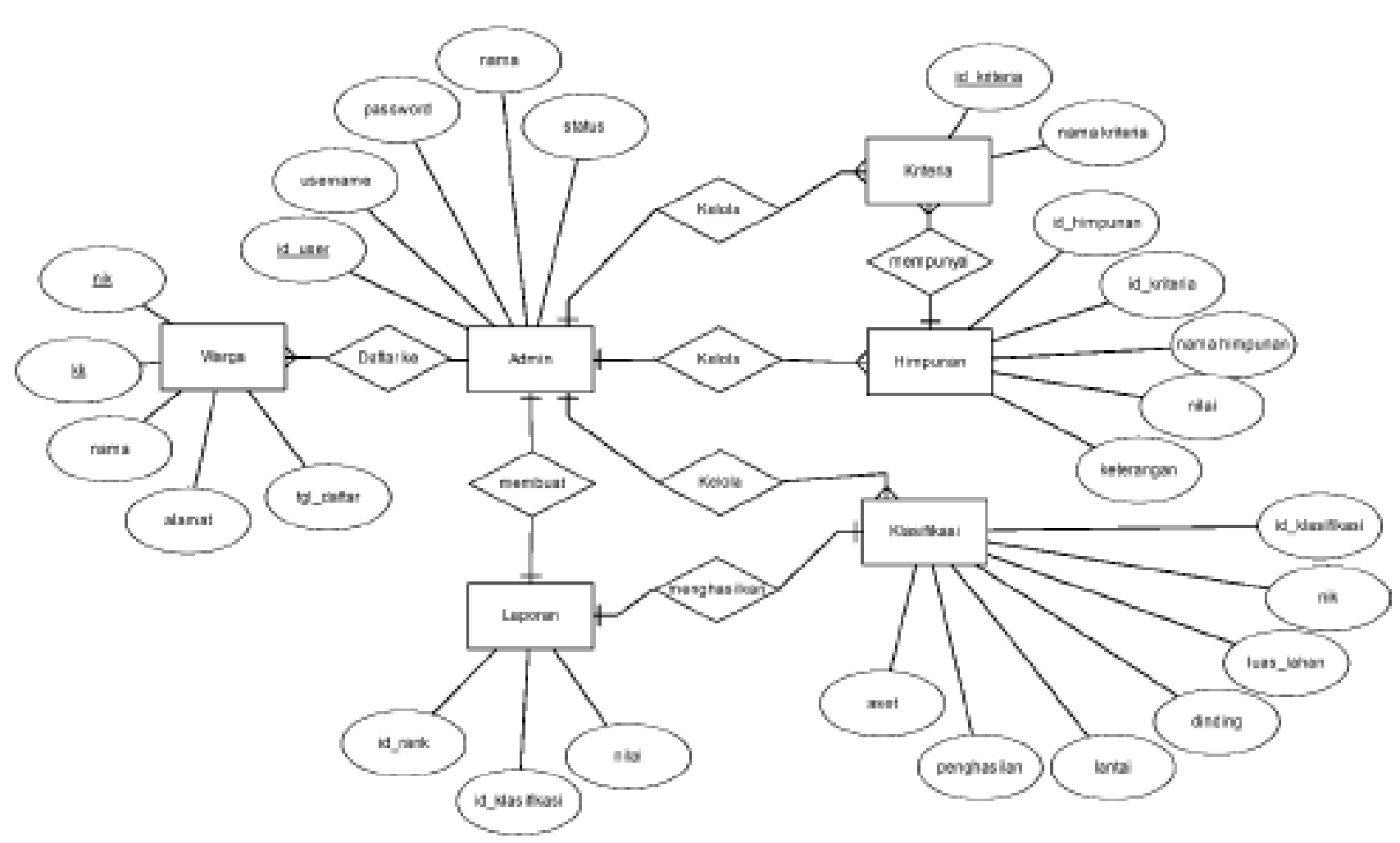

Gambar 2 Rancangan ERD 


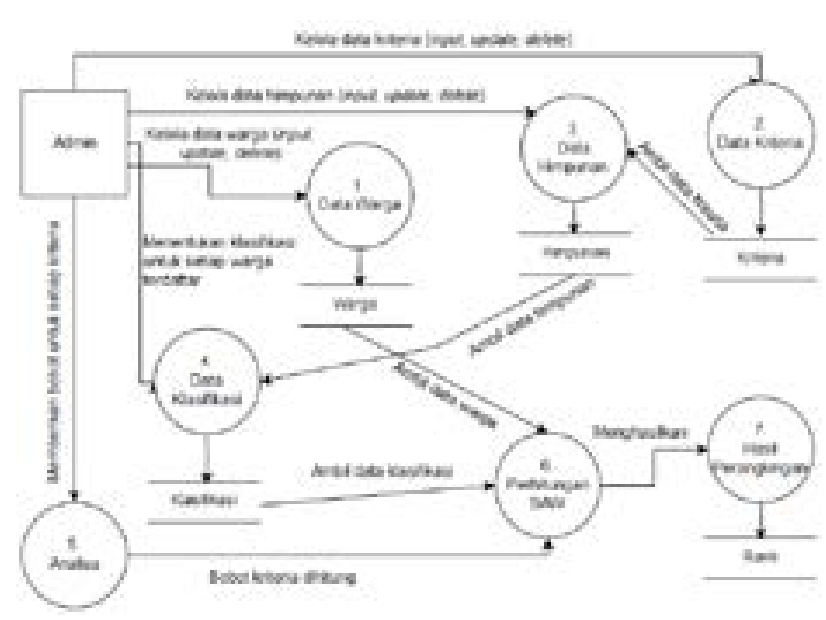

Gambar 4 Diagram DFD level 0

\section{HASIL DAN PEMBAHASAN}

\section{A. Perhitungan SAW}

Berdasarkan penelitian yang dilakukan di kelurahan Tegal Alur, alternatif yang akan dirangking adalah data warga. Sampel data warga yang akan diseleksi dapat dilihat pada Tabel 1.

Tabel 1 Data warga

\begin{tabular}{ll} 
NAMA & ALAMAT \\
\hline BONIHA & IL.Manyar Dalam RT 005 RW 015 \\
\hline AMNAH & JL. Lmgkangan 3 RT 014 RW 003 \\
\hline ALMI & GgDamai 3 RT 006 RW 008 \\
\hline
\end{tabular}

Kriteria yang dibutuhkan dalam proses perhitungan SAW dapat dilihat pada Tabel 2.

Tabel 2 Data kriteria

\begin{tabular}{cc} 
KODE & NAMA KRIIERIA \\
\hline $\mathrm{C} 1$ & Luas Lahan \\
\hline $\mathrm{C} 2$ & Dinding \\
\hline $\mathrm{C} 3$ & Lantai \\
\hline $\mathrm{C} 4$ & Peaghasilan \\
\hline $\mathrm{C} 5$ & Aset \\
\hline
\end{tabular}

Pada Tabel 3 ditampilkan data himpunan yang merupakan lanjutan dari kriteria yang berisi nilainilai yang nantinya akan diperlukan untuk proses perhitungan. Pada tabel 4 ditentukan bobot kriteria yang merupakan tingkat kepentingan dari masingmasing kriteria. Pada Tabel 5 ditampilkan data klasifikasi yang berisi himpunan setiap kriteria dari masing-masing alternatif dan kemudian pada tabel 6 dilakukan normalisasi awal sesuai dengan nilai himpunan yang telah ditentukan.

Sehingga diperoleh matrix Normalisasi keputusan $\mathrm{X}$ yang didapat dari rating keccocokan pada setiap alternatif $\left(A_{i}\right)$ dengan setiap kriteria $\left(C_{j}\right)$.
Tabel 3 Data himpunan

\begin{tabular}{|c|c|c|}
\hline Kriteria & Himpeman & Nila: \\
\hline \multirow{2}{*}{ Luas Lahan } & on $16 \mathrm{M} 2$ orang & 0 \\
\hline & $>16 \mathrm{M} 2$ orag & 1 \\
\hline \multirow{4}{*}{ Dinding } & Bambra & 25 \\
\hline & Triplek & 50 \\
\hline & Papan & 75 \\
\hline & Tembok & 100 \\
\hline \multirow{4}{*}{ Lantai } & Tanah & 25 \\
\hline & Kayu & 50 \\
\hline & Semen & 75 \\
\hline & Keransik & 100 \\
\hline \multirow{2}{*}{ Penghasilam } & $=5000000$ & 0 \\
\hline & $>5000000$ & 1 \\
\hline \multirow{2}{*}{ Aset } & $<-5000000$ & 0 \\
\hline & $>5000000$ & 1 \\
\hline
\end{tabular}

Tabel 4 Bobot kriteria
\begin{tabular}{|c|c|c|}
\hline Kode Kriteria & Bobot & Keterangan \\
\hline C1 & 5 & Sangat Baik \\
\hline C2 & 4 & Baik \\
\hline C3 & 3 & Sedang \\
\hline C4 & 2 & Rendah \\
\hline C5 & 1 & Sangat Rendah \\
\hline
\end{tabular}

Tabel 5 Data klasifikasi

\begin{tabular}{|c|c|c|c|c|c|}
\hline \multirow{2}{*}{$\begin{array}{c}\text { Wargn } \\
\text { Pemohon }\end{array}$} & \multicolumn{5}{|c|}{ Kinterna } \\
\hline & $\mathrm{Cl}$ & $\mathrm{C2}$ & C3 & $\mathrm{C} 4$ & $\mathrm{CS}$ \\
\hline BON: & 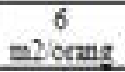 & Trpilex: & Tanah & 1000000 & $\$ 00000$ \\
\hline AMNAH & $\begin{aligned} & 6 \\
= & 2 \mathrm{erang}\end{aligned}$ & Tryplek & tanah & 1000000 & 300000 \\
\hline निया & $\begin{array}{c}8 \\
=2 \text { crial }\end{array}$ & Triplek & sencen & 1300000 & 400000 \\
\hline
\end{tabular}

Tabel 6 Tabel normalisasi awal

\begin{tabular}{|c|c|c|c|c|c|}
\hline \multirow{2}{*}{ Alternatif } & \multicolumn{5}{|c|}{ Kriteria } \\
\cline { 2 - 6 } & $\mathrm{Cl}$ & $\mathrm{C} 2$ & $\mathrm{C} 3$ & $\mathrm{C4}$ & $\mathrm{C5}$ \\
\hline BONIHA & 6 & 50 & 25 & 1000000 & 400000 \\
\hline AMNAH & 6 & 50 & 25 & 1000000 & 300000 \\
\hline ALMII & 8 & 50 & 75 & 1300000 & 400000 \\
\hline
\end{tabular}

$$
X=\left[\begin{array}{lllll}
6 & 50 & 25 & 1000000 & 400000 \\
6 & 50 & 25 & 1000000 & 300000 \\
8 & 50 & 75 & 1300000 & 400000
\end{array}\right]
$$

Selanjutnya melakukan langkah normalisasi matriks keputusan $X$ dengan cara menghitung nilai rating kinerja ternormalisasi $\left(r_{i j}\right)$ dari alternatif $\left(A_{i}\right)$ pada kriteria $\left(\mathrm{C}_{\mathrm{j}}\right)$. Karena atribut kriteria dalam kasus adalah cost, maka digunakan rumus: 


$$
R_{i j}=\frac{\operatorname{Min}_{i}\left(x_{i j}=\right.}{x_{i i}}
$$

Perhitungan Normalisasi Matriks untuk A1 :

$$
\begin{aligned}
& R_{11}-\frac{M \operatorname{in}(6,6,8)}{6}-\frac{6}{6}-1 \\
& R_{12}-\frac{M \operatorname{in}(50,50,50)}{50}-\frac{50}{50}-1 \\
& R_{13}-\frac{M i n(25,25,75)}{25}-\frac{25}{25}-1 \\
& R_{14}=\frac{M \operatorname{in}(1000000,1000000,1300000)}{1000000}=\frac{1000000}{1000000}=1 \\
& R_{15}=\frac{M \operatorname{in}(400000,300000,400000)}{400000}=\frac{300000}{400000}=0,75
\end{aligned}
$$

Perhitungan Normalisasi Matriks untuk A2 :

$$
\begin{aligned}
& R_{21}-\frac{M \min (6,6,8)}{6}-\frac{6}{6}-1 \\
& R_{22}-\frac{\operatorname{Min}(50,50,50)}{50}-\frac{50}{50}-1 \\
& R_{23}-\frac{\operatorname{Min}(25,25,75)}{25}-\frac{25}{25}-1 \\
& R_{24}=\frac{\operatorname{Min}(1000000,1000000,1300000)}{1000000}=\frac{1000000}{1000000}=1 \\
& R_{23}=\frac{\operatorname{Min}(400000,300000,400000)}{300000}=\frac{300000}{300000}=1
\end{aligned}
$$

Perhitungan Normalisasi Matriks untuk A3 :

$$
\begin{aligned}
& R_{31}-\frac{M i n(6,6,8)}{8}-\frac{6}{8}-0,75 \\
& R_{32}-\frac{M i n(50,50,50)}{50}-\frac{50}{50}-1 \\
& R_{33}-\frac{\operatorname{Min}(25,25,75)}{75}-\frac{25}{75}-0,333 \\
& R_{21}=\frac{\operatorname{Min}(1000000,1000000,1300000)}{1300000}=\frac{1000000}{1300000}=0,709 \\
& R_{25}=\frac{\operatorname{Min}(400000,300000,400000)}{400000}=\frac{300000}{400000}=0,75
\end{aligned}
$$

Tahap selanjutnya adalah mencari nilai dari setiap alternatif, dimana nilai dari setiap kriteria akan dikalikan dengan bobot kriteria tersebut dan dijumlahkan semua kriterianya.seperti yang terlihat pada rumus berikut.

$$
V_{t}=\sum_{j=1}^{n} w_{j} r_{i, j}
$$

$$
\begin{aligned}
\text { BONIH A } & =(5 \times 1)+(4 \times 1)+(3 \times 1)+(2 \times 1)+(1 \times 0,75) \\
& =5+4+3+2+0,75 \\
& =14,75 \\
\text { AMNAH } & =(5 \times 1)+(4 \times 1)+(3 \times 1)+(2 \times 1)+(1 \times 1) \\
& =5+4+3+2+1
\end{aligned}
$$

$$
\begin{aligned}
& =15 \\
\text { ALMI } & =(5 \times 0,75)+(4 \times 1)+(3 \times 0,33)+(2 \times 0,769)+(1 \times 0,75) \\
& =3,75+4+1+1,538+0,75 \\
& =11,038
\end{aligned}
$$

Maka didapatkan hasil perangkingan berdasarkan nilai terbesar seperti pada Tabel 7 .

Tabel 7 Tabel perangkingan

\begin{tabular}{|c|c|c|}
\hline No & Alvervatif & Nilai Akhir \\
\hline 1 & AMNAH & 15 \\
\hline 2 & BONIH A & 14,75 \\
\hline 3 & ALMI & 11,038 \\
\hline
\end{tabular}

\section{B. Tampilan Sistem}

Tampilan gambar 5 merupakan tampilan user interface yang menampilkan data warga pemohon BPNT. User dapat melakukan pengelolaan terhadap data warga.

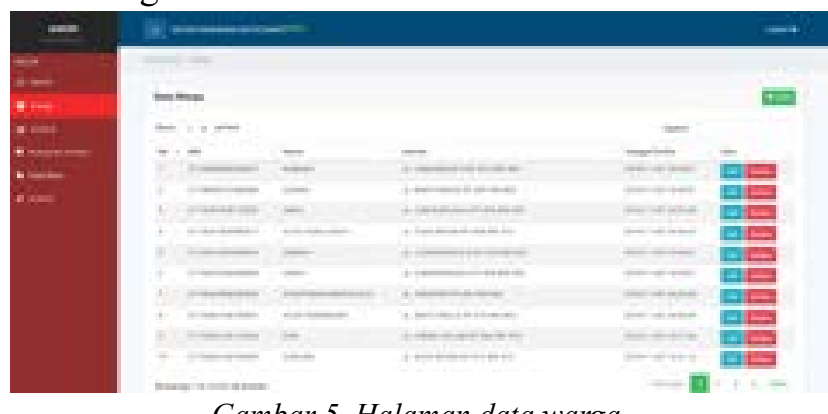

Gambar 5 Halaman data warga

Tampilan Gambar 6 merupakan tampilan user interface yang menampilkan data kriteria yang dibutuhkan untuk mengklasifikasikan data warga.

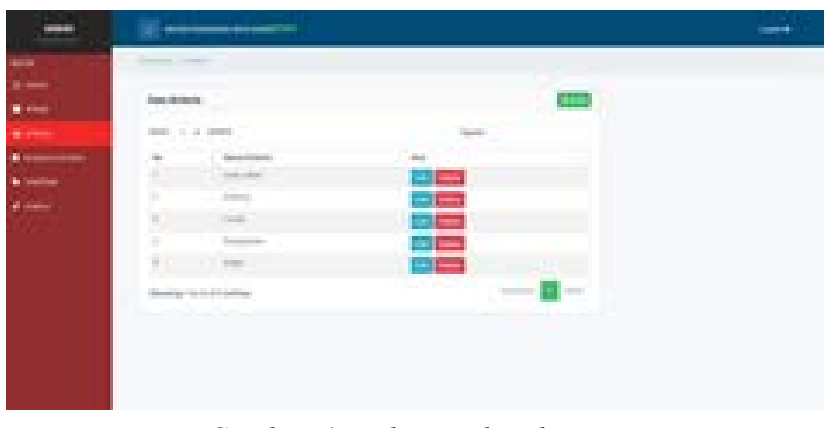

Gambar 6 Halaman data kriteria

Tampilan Gambar 7 merupakan tampilan user interface yang menampilkan data himpunan kriteria / sub kriteria. Jika alternatif (data warga) memiliki kriteria dengan nilai 1 maka secara otomatis alternatif tersebut dikatakan sebagai warga yang tidak berhak menerima BPNT.

Tampilan Gambar 8 merupakan tampilan user interface yang menampilkan data klasifikasi dan form input data klasifikasi. Data klasifikasi di input berdasarkan kondisi kriteria dari masing-masing alternatif. 

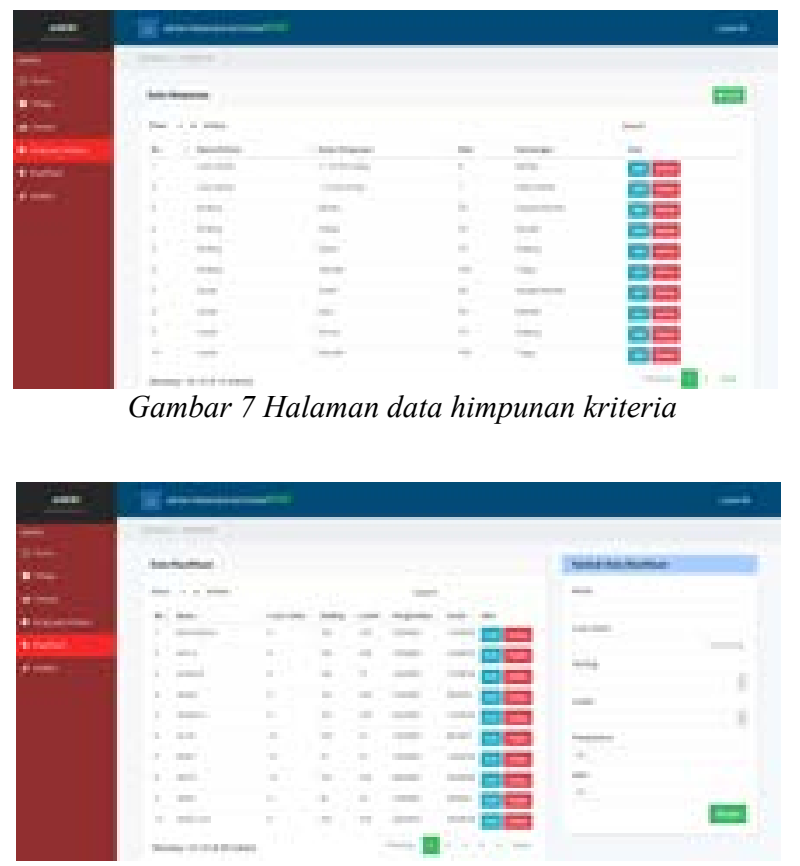

Gambar 8 Halaman data klasifikasi

Tampilan Gambar 9 merupakan tampilan user interface pada saat pengguna melakukan penentuan bobot masing-masing kriteria.

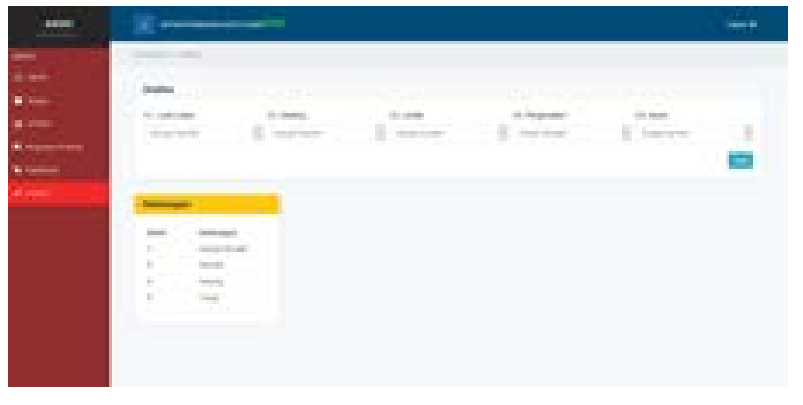

Gambar 9 Form analisa

Tampilan Gambar 10 merupakan tampilan user interface yang menampilkan perhitungan dan rekomendasi sebagai bahan pertimbangan untuk menentukan calon penerima BPNT. Semakin besar nilai akhir perhitungan maka semakin tinggi tingkat rekomendasi.

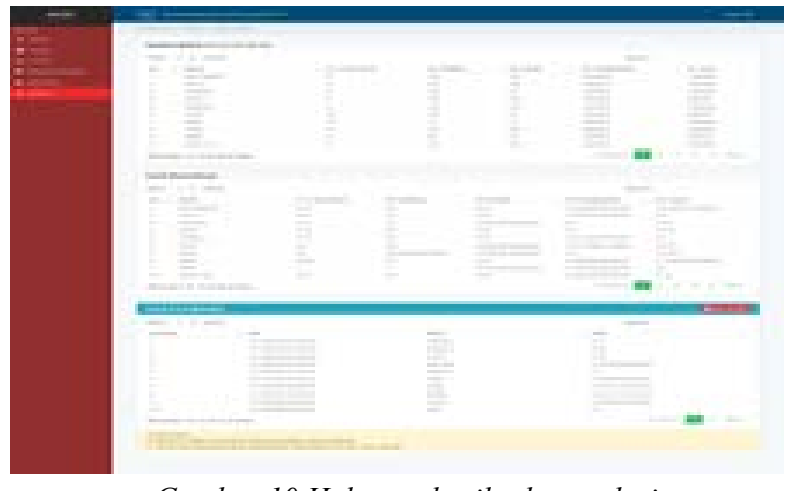

Gambar 10 Halaman hasil rekomendasi

\section{Hasil Pengujian}

Berikut ini adalah hasil pengujian yang dilakukan melalui aplikasi dengan menampilkan output perangkingan sebanyak $25 \%$ dari data warga yang berhasil penulis peroleh seperti pada Tabel 8:

Tabel 7 Hasil rekomendasi sistem

\begin{tabular}{|c|c|c|c|}
\hline No & NIK & NAMA & NILAI \\
\hline 1 & 31730610076500004 & AMNAH & 4.8 \\
\hline 2 & 31730643107200003 & BONIH A & 4.55 \\
\hline 3 & 31730645096300004 & AISAH & 4.35 \\
\hline 4 & 31730641067900009 & ADEIENT & 3.73333333 \\
\hline 5 & 31730643027200005 & AMINAH & 3.5 \\
\hline 6 & 32161310065500001 & AMIH & 3.46666667 \\
\hline 7 & 31730648086400009 & ALMI & 3.44871795 \\
\hline 8 & 31730671124510001 & BONIS & 3.41212121 \\
\hline 9 & 31730645015500006 & AMAH & 3.33333333 \\
\hline 10 & 31730655066700004 & AINI & 3.1 \\
\hline 11 & 3173064106700007 & ACAH & 3.08333333 \\
\hline 12 & 3173065207650015 & AISAH & 3.01190476 \\
\hline
\end{tabular}

Kemudian penulis melakukan perbandingan dengan hasil penerimaan BPNT dengan menggunakan data yang sama. Berdasarkan perbandingan data di atas hasil yang ditampilkan pada aplikasi juga terdapat pada hasil penerimaan BPNT yang penulis terima. Sehingga dapat disimpulkan bahwa sistem pendukung keputusan ini layak dijadikan sebagai aplikasi rekomendasi calon penerima BPNT.

\section{SIMPULAN}

Berdasarkan pembahasan hasil penelitian yang telah dibahas di bab sebelumnya, maka dalam penelitian ini dapat diambil kesimpulan bahwa: (1) Pejabat di Kelurahan Tegal Alur dapat lebih terbantu dalam mengelola data warga, kriteria, dan klasifikasi serta perhitungan rekomendasi karena telah menggunakan sistem yang terkomputerisasi; (2) Dengan perhitungan menggunakan metode SAW sistem pendukung keputusan ini dapat memberikan informasi kepada pejabat terkait berupa rekomendasi warga yang berhak menerima BPNT dengan output berupa perangkingan berdasarkan nilai alternatif dari terbesar hingga terkecil. Besarnya nilai alternatif menunjukan besarnya tingkat rekomendasi; dan (3) Sistem pendukung keputusan ini layak dijadikan aplikasi rekomendasi penerima BPNT karena melalui pengujian, sistem menampilkan hasil yang sama.

\section{DAFTAR RUJUKAN}

[1] Badan Pusat Statistik, Garis Kemiskinan Menurut Kabupaten/Kota. 2017. [Online]. Diakses pada 05 September 2018 dari https://www.bps.go.id/ dynamictable/2017/08/03/1264/garis-kemiskinan- 
menurut-kabupaten-kota-2015---2017.html. Diakses pada 05 September 2018.

[2] A. S. Rini, D. Soyusiawaty. Sistem Pendukung Keputusan Seleksi Penerimaan Beras Untuk Keluarga Miskin Dengan Metode Simple Additive Weighting. Jurnal Sarjana Teknik Informatika, Vol. 2, No. 2, hlm 1196-1205, e-ISSN: 2338-5197. 2014

[3] Y. Radhitya, F. N. Hakim, \& A. Solechan. Rancang Bangun Sistem Pendukung Keputusan Penentuan Penerima Beasiswa Dengan Metode SAW. Journal Speed - Sentra Penelitian Engineering dan Edukasi, Vol. 8, No. 2, hlm 23-32, ISSN: 1979-9330. 2016

[4] Kementerian Sosial Republik Indonesia, Bantuan Pangan Non Tunai. [Online]. Diakses pada 05 September 2018 dari https://www.kemsos.go.id/page/ bantuan-pangan-non-tunai.

[5] I. Septiana, et al.. Sistem Pendukung Keputusan Penentu Dosen Penguji Dan Pembimbing Tugas Akhir Menggunakan Fuzzy Multiple Attribute Decission Making Dengan Simple Additive Weighting. Jurnal Online Informatika, Vol. 1, No. 1, hlm 43-50, ISSN 2527-9165. 2016

[6] R. Fauzan, Y. Indrasary, \& N. Muthia. Sistem Pendukung Keputusan Penerimaan Beasiswa Bidik Misi di POLIBAN Dengan Metode SAW Berbasis Web. Jurnal Online Informatika, Vol. 2, No. 2, hlm 7983, DOI: 10.15575/join.v2i2.101. 2017

[7] Frieyadie. Penerapan Metode Simple Additive Weighting (SAW) Dalam Sistem Pendukung Keputusan Promosi Kenaikan Jabatan. Jurnal Pilar Nusa Mandiri, Vol. XII, No. 1, hlm 37-45, ISSN: 1978-1946. 2016
[8] H. Adela,et al. Selection of Dancer Member Using Simple Additive Weighting. International Journal of Engineering \& Technology, Vol. 7, No. 3, hlm 10961107, DOI: 10.14419/ijet.v7i3.11983. 2018

[9] T. Y. Chen. An Interactive Signed Distance Approach for Multiple Criteria Group Decision-Making Based on Simple Additive Weighting Method with Incomplete Preference Information Defined by Interval Type2 Fuzzy Sets. International Journal of Information Technology \& Decision Making, Vol. 13, No. 5, hlm 979-1012, DOI: 10.1142/S0219622014500229. 2013

[10] H. Shakouri, M. Nabaee, \& S. Aliakbarisani. A Quantitative Discussion on the Assessment of Power Supply Technologies: DEA (Data Envelopment Analysis) and SAW (Simple Additive Weighting) as complementary methods for the "Grammar". Energy, Vol. 64, hlm 640-647, DOI: 10.1016/j. energy.2013.10.022. 2014

[11] D. P. Kaliszewski. Simple Additive Weighting - a Metamodel for Multiple Criteria Decision Analysis Methods. Energy, Vol. 54, hlm 155-161, DOI: 10.1016/j.eswa.2016.01.042. 2016

[12] Y. J. Wang. A Fuzzy Multi-criteria Decision Making Model Based on Simple Additive Weighting Method and Relative Preference Relation. Applied Soft Computing, Vol. 30, hlm 412-420, DOI: 10.1016/j. asoc.2015.02.022. 2015 